\title{
BÁNÓCZI JÓZSEF \\ (1849-1926)
}

\author{
HOPPÁL BULCSÚ
}

Születési nevén Weisz József, magyar filozófus, teológus, irodalomtörténész, pedagógus, Alexander Bernáttal a Filozófiai Írók Tára címü filozófiatörténeti sorozat szerkesztője, mellyel jelentősen megalapozták a modern magyar filozófiai műnyelv létrejöttét, saját bölcseleti álláspontot ugyanakkor nem alakított ki. Gimnáziumi tanulmányait Veszprémben és Budapesten végezte. 1869-ben a budapesti, 187072-ben a bécsi, 1873-74-ig a berlini, göttingeni és lipcsei egyetemeken, 1875-ben Párizsban és Londonban tanult, majd ugyanebben az évben avatták doktorrá Lipcsében. 1875-től Budapesten a VIII. kerületben középiskolai tanár, majd 1878-tól a Budapesti Tudományegyetemen a filozófiatörténet és propedeutika magántanára; később 1909-ben címzetes nyilvános rendkívüli tanárrá nevezték ki. A budapesti egyetemen haláláig oktatott. A Magyar Tudományos Akadémia 1879-ben választotta tagjai közé. 1882-től a Kisfaludy Társaság tagja lett. 1887-től tanára és igazgatója volt az Országos Izraelita Tanítóképző Intézetnek. Már az 1870-es évektől tudományos, olykor ismeretterjesztő cikkei jelentek meg a legkülönbözőbb lapokban: Magyar Nyelvőr, Fővárosi Lapok, Magyar Tanügy, Nyelvtudományi Közlemények, Természettudományi Közlöny, Ország-Világ, Philologiai Közlöny, Nemzeti Nönevelés, Egyetértés, Pesti Napló és az Országos Izraelita Tanító-Egyesület Értesítője.

Bánóczi a magyarországi zsidóság emancipációjához és neveléséhez irodalmi-tudományos szellemi termékekkel járult hozzá. 1884-től 1893-ig Bacher Vilmossal szerkesztette a Magyar-Zsidó Szemlét, alapításától haláláig pedig az Izraelita Magyar Irodalmi Társulat évkönyveit. A Magyar-Zsidó Szemle magas színvonalon foglalkozott kora társadalmi és tudományos kérdéseivel. Ebben a folyóiratban tartalmas viták folytak a zsidó recepció és autonómia kérdéseiről, állandó orgánuma volt a magyar nyelven közérthető módon megszólaló zsidó felekezeti hátterü tudománynak is. A szerkesztői elvei szerint „hazafias és közhasznú” Magyar-Zsidó Szemle az egyre inkább magyarosodó neológ zsidóság lapja volt. Bánóczi mint az Országos Izraelita Tanítóképző Intézet igazgatója megírta annak történetét (Az Országos Izraelita Tanítóképzö-Intézet története: 1857-1897, 1897), és a magyar nyelvüség és magyarsághoz való hüség szellemiségével átitatva teljességgel megreformálta és a modern pedagógia legmagasabb színvonalán álló intézetévé tette 
az iskolát. Kifejezett célja volt, hogy mind a zsidó felekezetű tanítóképző intézetben, mind pedig az Országos Rabbiképző Intézetben, melynek szintén tanára volt (történetét megírta: „Az Országos Rabbiképző Intézet első évtizedének története”, A Budapesti Országos Rabbiképzö Intézet X. Értesitöje az 1886/87-iki Tanévről, 1888; ugyanezt németül is megjelentette), az általa szerkesztett magyar nyelvi és irodalmi tankönyvekkel a diákok és leendő rabbik hazaszeretetét is erősítse. Szerkesztésében stilisztikai, tan- és olvasókönyvek sora jelent meg. Mindemellett a szegényebb diákok megsegitésére segélyegyletet és tanítóképző-internátust hozott létre.

Bánóczi a korabeli polgárosodó, emancipálódó zsidóság egy további platformján is kimagaslót alkotott szervezői, szerzői, szerkesztői munkájával. Egyik alapítója (1894) és hosszú éveken át titkára volt az Izraelita Magyar Irodalmi Társulatnak. Ö szerkesztette mindvégig a társulat évkönyveit, amelyekben munkáikkal sorban megszólaltak Magyarország legkiválóbb rabbijai, zsidó írói, költői, tudósai. Az Izraelita Magyar Irodalmi Társulatnak saját könyvsorozata is volt, amelyben a legkiválóbb vallástudományi monográfiák és kora filológiai tudományosságát legmagasabb szinten tükröző fordítások jelenhettek meg. Itt jelent meg többek között először - Bánóczi előszavával - a Guttman Mihály és Harmos Sándor szerkesztette Péchi Simon szombatos imádságos könyve (1915) és a Magyar-zsidó oklevéltár első kötete (1903). A judaisztikai monográfiák megjelentetése mellett a társaság legnagyobb vállalkozása a teljes héber Szentírás első magyar nyelvű fordításának kiadása négy kötetben. A szerkesztők Bánóczi mellett Bacher Vilmos és Krausz Sámuel voltak. Bánóczi kiválóan tudott héberül, a fordítási szöveg szakmai és nyelvi lektori átvizsgálása őt dicséri.

Irodalomtudományi és nyelvészeti munkássága hasonlóképpen nagy spektrumot ölel fel. Az egyetemes magyar irodalom szempontjából szinte felbecsülhetetlen, milyen komoly kiadói és szerkesztői munkát végzett, mégis irodalomtörténeti szempontból két releváns müvet kell megemlítenünk, amelyek bölcseleti tartalommal is bírnak. A Magyar Tudományos Akadémia által díjazott pályamű a piarista tanár, nyelvész, a magyar történeti nyelvészet megalapozójának tekintett Révai Miklós életét és munkásságát feldolgozó monográfia (Révai Miklós élete és munkái, 1879). Bánóczi ebben a müben nemcsak akkurátusan bemutatja a pap-költőt, a nyelvészt, hanem magyar nyelven elöször alkalmazza Taine miliö-elméletét. Így Révai szellemi fejlődésében legfontosabb mozzanatnak tartja filozófiai tanulmányait, mondván, a „philosophiai tanulmányok elvont gondolkodáshoz szoktatnak, fölvilágosítják az észt önnön eljárása felől, ezer és ezer serkentő gondolatot ébresztenek" (Révai Miklós élete és munkái, 35). Bánóczi tollából egy, a magyar nyelv megújításáért örökösen küzdő tudósember képe bontakozik ki. Elmondhatjuk, Révaiban, a magyar nyelv és a magyar gondolat iránt érzett mély elkötelezettségben saját magát látta: „Révai hangsúlyozza, hogy Euclides titkait magyar nyelven oldja, hogy az építés tudományát magyar nyelven irja meg, hogy a görög méretet a 
magyar nyelvre is alkalmazza, hogy a physika is magyar nyelven szólal meg - szóval Révai mindent a nyelv szempontjából néz és ítél” (i. m. 79).

Említett irodalomtudományi müvénél közel kétszer terjedelmesebb a Kisfaludy Társaság megbízásából írott Kisfaludy Károly és munkái (I-II., 1882-83) címü könyve. Nyelvezet szempontjából ez a monográfia némileg eltér a Révai-dolgozattól, könnyedebb, elbeszélő formában tárja elénk még érveit is. Az epikusság frissességet, képszerüséget eredményezett, mely Beöthy Zsolt, kora konzervatív irodalomtörténész-fejedelme szerint a könyvet a magyar írói életrajzírás fejlődésének egyik legeredetibb termékévé tette, és az európai biográfiák sorába emelte. A monográfiát követően Kisfaludy több művét külön is kiadta. A Bánóczi által szerkesztett további klasszikus magyar irodalmi alkotások előszavait és jegyzeteit közösen jellemzik a hagyományos, a forma és a tartalom egysége mellett érvelö esztétikai-filozófiai elvek. Bánóczi kiadta többek között Petőfi Sándor (1901), Berzsenyi Dániel (1902), Csokonai Vitéz Mihály (1904) összes műveit, gondozta Zrínyitől a Szigeti veszedelmet, Mikes Kelemen leveleit és Arany Jánostól a Toldi estéjét is.

Filozófiai tevékenysége egyenes folytatása irodalmi, nyelvészeti, filológiai munkásságának. A Magyar Nyelvőr című folyóiratban 1876-tól 1882-ig cikksorozatot közölt „A bölcselet magyar nyelve” címmel. Ez a mü tekinthető egyedül Bánóczi saját filozófiai elveit tartalmazó írásnak. Dolgozatának érvelése abból indul ki, hogy a közös filozófiai münyelv megteremtésekor tekintetbe kell venni a „magyar nyelvkincset” és „nyelvtényeket”, melyekről „legjobb íróink”, a „nép” és a köznyelv is tudósítanak. Bánóczi szerint a nyelvünkben meglévő filozófiai kincset ki kell aknázni, s nemcsak bevezetni egy-egy bölcseleti fogalmat magyarul, hanem az értelmét is kimutatni. Egy újonnan bevezetett filozófiai fogalom helyességét nem annak hosszúsága-rövidsége jelenti, hanem kizárólag szabatossága. Arra a kérdésre, hogy lehet-e magyar nyelven tudományos filozófiát művelni, Bánóczi a magas szintű magyar irodalmi nyelv létére utal: „A mely nyelv már odáig fejlődött, hogy hangot adhat érzésnek és képzelésnek, kívánásnak és sóvárgásnak, az mért ne fejezhetne ki gondolatot is? Hiszen a nép nem csak érez és kíván, hanem gondolkodik is" (i. m. 200). Érvelése szerint tehát ahol önálló nemzeti irodalom van, ott a nyelv - ebben is felmutatva zsenijét - a bölcselet legmagasabb szintű müvelésére is alkalmas. A nyugati nyelvek - a rokon-nyelv tapasztalat okán - a latinhoz és göröghöz fordulnak, a magyar azonban „a meglévő nyelvanyagból” képes „a szükséges szót a nyelv törvényei szerint megteremteni” (i. m. 201). Ez Bánóczi szerint a magyar nyelv „életrevalóságára s fejlődési képességére mutat” (uo.), mert - és ez nyelvfilozófiai fejtegetéseinek végső konklúziója - a nyelv fejlődése egyenlő annak helyes müvelésével.

A Bánóczi által alkotott filozófiai müszavak jó része ma is él. Ehhez hozzájárultak hatalmas fordítás-projektjei. A Magyar Tudományos Akadémia könyvkiadó 
vállalatának megbízásából lefordította George Henry Lewes háromkötetes $A$ philosophia története: Thalestöl Comteig címü müvét (1876-78). Legnagyobb vállalkozása mégis az Alexander Bernáttal együtt szerkesztett Filozófiai Írók Tára sorozat, melyben 1881-től 1918-ig összesen 29 kötet jelent meg. A filozófiai műnyelv magyarítására először a XVII. közepén Apáczai Csere János tett kísérletet Encyclopaediájában. Apáczai műve azonban visszhangtalan maradt. A Filozófiai Îrók Tára és a XIX. század végén egyre-másra megjelenő önálló magyar nyelvü folyóiratok azonban beteljesítették ezt a folyamatot. A Filozófiai Írók Tára ilyen értelemben nemcsak egy sorozat volt, hanem a magyar bölcselet intézményesülésének egyik legjelentősebb állomása, mely döntően hozzájárult a filozófiai szókincs megszilárdulásához. A Filozófiai Írók Tára fordításait szinte azonnal be is emelték az egyetemi oktásba, felhasználva a szerkesztöi, lektorálási tapasztalatokat. Bánóczi két fordításban is részt vett: Arthur Schopenhauer válogatott tanulmányait adta közre (1882), és lefordította - Alexander Bernáttal - Immanuel Kant A tiszta ész kritikája című müvét (1891). A kanti Ding an sich kifejezés „magánvaló”-ként való fordítása szintén töle ered.

\section{TOVÁBBI IRODALOM}

Bánóczi József: „A bölcselet magyar nyelve.” Magyar Nyelvőr (1876-1882, cikksorozat).

Bánóczi József: Révai Miklós élete és munkái (1879).

Bánóczi József: Kisfaludy Károly és munkái (I-II., 1882-83).

Schopenhauer, Arthur: 1. A halálról; 2. A faj élete; 3. A tulajdonságok öröklése; 4. A nemi szerelem metafizikája. Függelék a negyedik értekezéshez; 5 . Az élethez való akarat igenléséröl; 6. Az élet semmiségéről és gyötrelméről. Ford., jegyz. Bánóczi József (1882, Filozófiai Írók Tára, II. kötet).

Kant, Immanuel: A tiszta ész kritikája. Ford., jegyz. Alexander Bernát, Bánóczi József (1892, Filozófiai Írók Tára, IX. kötet).

Emlékkönyv Bánóczi Józsefnek születése hetvenedik évfordulójára: 1919 július 4. (1919).

Kornis Gyula: „Bánóczi József.” Kornis Gyula: Magyar filozófusok (1944, 191-194). 